\title{
EFEKTIVITAS PERMAINAN TRADISIONAL ENGKLEK DALAM MENINGKATKAN HASIL BELAJAR MATEMATIKA
}

\author{
Laras Retno Widyastuti ${ }^{1)}$ \\ Lina Revilla Malik ${ }^{2)}$ \\ Abdul Razak ${ }^{3)}$ \\ ${ }^{1), 2), 3)}$ Program Studi Pendidikan Guru Madrasah Ibtidaiyah, IAIN Samarinda \\ Email: ${ }^{3)}$ razakabdul180290@gmail.com
}

\begin{abstract}
ABSTRAK
Tujuan dari penelitian ini adalah untuk mengetahui efektivitas permainan tradisional engklek dalam meningkatkan hasil belajar matematika siswa kelas 2 SD Muhammadiyah 1 Anggana tahun pelajaran 2019/2020. Penelitian ini merupakan penelitian kuantitatif. Populasi dan sekaligus sampel penelitian ini adalah siswa kelas kelas 2 SD Muhammadiyah 1 Anggana berjumlah 21 siswa. Desain penelitian yang digunakan One-grup pretest and posttest design. Teknik pengumpulan data yang digunakan dalam penelitian ini berupa tes hasil belajar matematika yang sebelumnya dilakukan uji validitas dan reliabilitas, lembar observasi, dan dokumentasi. Teknik analisis data menggunakan uji-t ( $t$-test). Hasil analisis data menunjukkan bahwa $\mathrm{t}_{\text {hitung }}=5,7>\mathrm{t}_{\text {tabel }}=1,725$ artinya permainan tradisional engklek efektif dalam meningkatkan hasil belajar matematika siswa.
\end{abstract}

Kata kunci: Permainan Engklek, Hasil Belajar Matematika.

\begin{abstract}
The purpose of this research was to determine the effectiveness of the traditional engklek game in improving mathematics learning outcomes of second Grade students of Elementary School Muhammadiyah 1 Anggana in the academic year 2019/2020. This research is quantitative research. The population and at the same time the sample of this research were second grade students of Elementary School Muhammadiyah 1 Anggana totaling of 21 students. The research design used was One-group pretest and posttest design. Data collection techniques used in this research were in the form of tests of mathematics learning outcomes that were previously tested for validity and reliability, observation sheets, and documentation. Data analysis techniques using the t-test (t-test). Analysis result is $t_{\text {count }}=5,7>t_{\text {table }}=1,725$ means that the traditional engklek game is effective in improving student mathematics learning outcomes.
\end{abstract}

Keywords: Engklek Game, Mathematics Learning Outcomes 


\section{PENDAHULUAN}

Salah satu ilmu yang tidak pernah lepas dari kehidupan dan terus menerus dipelajari adalah matematika. Pelajaran matematika untuk pertama kali diterima secara formal oleh siswa pada waktu mereka duduk di bangku kelas 1 SD. Frengky (2008) mengemukakan bahwa siswa kelas 1 SD mempunyai kesempatan yang besar untuk menyukai atau pun tidak menyukai matematika. Kelas 1 SD menjadi pintu gerbang pertama dalam perjalanan pelajar memasuki dunia matematika, dengan demikian pemahaman pembelajaran matematika menjadi suatu hal yang penting dikaji. Lebih lanjut Abdul Razak (2016) mengatakan jangan sampai matematika menjadi pelajaran yang membosankan dan sulit dan tidak terlihat sebagai sesuatu yang ada dalam kehidupan sehari-hari.

Realitanya masih banyak ditemukan siswa yang kesulitan dalam mengikuti pelajaran matematika khususnya materi nilai tempat. Sebagai contoh bilangan 45 dan 54. Angka 4 pada bilangan 45 memiliki nilai berbeda dengan angka 4 pada bilangan 54 karena tempatnya berbeda. Angka 5 pada bilangan 45 bernilai 5 satuan sedangkan angka 5 pada bilangan 54 bernilai 5 puluhan. Siswa kelas 2 SD Muhammadiyah Anggana 1 masih sangat kesulitan membedakannya.

Hal ini dibuktikan dengan hasil evaluasi pada akhir semester 2 yang menunjukkan bahwa terdapat 9 dari 21 siswa kelas 1 yang belum mencapai nilai $\mathrm{KKM}=60$ yang artinya nilai ketuntasan hanya 57\%. Hal ini juga dikemukakan oleh Yusri dan Sari (2017) bahwa siswa kurang memahami dan memaknai nilai tempat suatu bilangan. Savitri dkk (2019) menambahkan bahwa selain pemahaman materi, siswa juga kurang tertarik mengikuti pembelajaran terkhusus pada materi nilai tempat walaupun telah memanfaatkan media ice cream dan batang korek.

Dari segi usia siswa yang kurang matang dapat menyebabkan motivasi diri untuk belajar sangat kurang terutama dalam pelajaran matematika, karena anak usia kelas 1 SD masih lebih senang bermain sambil belajar. Suparman dan Agustini (2017) memandang bahwa permainan merupakan kebutuhan batiniah setiap anak karena dengan bermain mampu meningkatkan keterampilan dan pengembangan anak dengan suasana yang menyenangkan dan menarik. Ada banyak permainan yang dapat dikombinasikan dengan materi yang ada di sekolah dasar, misalnya permainan tradisional.

Siregar dan Lestari (2018) menyatakan permainan tradisional merupakan kegiatan yang menghibur dengan menggunakan alat sederhana dan tanpa alat yang merupakan warisan dari generasi ke generasi. Lebih lanjut permainan tradisional yang ditemukan adalah engklek, kelereng, dan batu serimbang. Hasanah dan pratiwi (2017) menyatakan perrmainan engklek di daerah banjar disebut sebagai bajujunggatan, yang mampu melatih kognitif anak dan mengenal konsep bilangan untuk mengingat nomor dalam setiap kotak. Lebih lanjut Razak dan Rumainur (2018) menyatakan dalam pelajaran matematika, tugas seorang guru menciptakan kondisi meyenangkan dan membangkitkan gairah minat siswa.

Permainan tradisional engklek adalah salah satu permainan tradisional 
yang dilakukan di luar rumah yang membuat minat siswa menjadi meningkat. Permainan yang dilakukan adalah dengan cara melom-pat pada suatu bidang datar yang digambar di atas tanah dengan membuat gambar kotak-kotak, kemudian melompat dengan satu kaki dari kotak satu ke kotak berikutnya. Permainan ini biasanya dilakukan perorangan dan berkelompok, biasa dimainkan oleh anak-anak perempuan namun tidak jarang juga anak laki-laki. Pada saat bermain engklek anak-anak juga bisa melakukannya sambil belajar.

Berangkat dari permasalahan tingkat ketuntasan materi nilai tempat di kelas 1 SD Muhammadiyah 1 Anggana yang masih sangat rendah dan pentingnya belajar sambil bermain terutama dalam penemuan konsep nilai tempat, maka tujuan penelitian ini untuk membuktikan bahwa permainan tradisional engklek efektif dalam meningkatkan hasil belajar matematika pada siswa sekolah dasar Muhammadiyah 1 Anggana.

\section{METODE PENELITIAN}

Penelitian ini dilaksanakan di kelas 2 SD Muhammadiyah 1 Anggana Kabupaten Kutai Kartanegara semester ganjil tahun pelajaran 2019/2020. Jenis penelitian yang digunakan dalam penelitian ini adalah penelitian kuantitatif. Penelitian ini menguji secara langsung apakah permainan tradisional engklek efektif terhadap hasil belajar matematika untuk materi nilai tempat. Populasi sekaligus sampel dalam penelitian ini adalah seluruh siswa kelas 2 SD Muhammadiyah 1 Anggana yang berjumlah 21 siswa.
Desain penelitian yang digunakan adalah One-grup pretest and posttest design (Sugiyono, 2015).

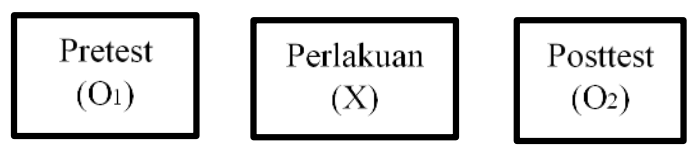

Gambar 1. Desain penelitian

Teknik pengumpulan data yang digunakan yaitu observasi, dokumentasi, dan tes hasil belajar matematika yang sebelumnya dilakukan uji validitas dan reliabilitas. Teknik analisis data untuk hasil belajar domain kognitif dalam penelitian ini menggunaka uji-t (Budiyono, 2016).

$$
\mathrm{t}=\frac{\overline{\mathrm{D}}-\mathrm{d}_{\mathrm{o}}}{\mathrm{s}_{\mathrm{d}} / \sqrt{\mathrm{n}}} \sim \mathrm{t}(\mathrm{n}-1) \quad \mathrm{D}=\mathrm{X}_{1}-\mathrm{X}_{2}
$$

Keterangan: $\mathrm{S}_{\mathrm{d}}=$ deviasi baku dari $\mathrm{D}$

$$
\begin{aligned}
\mathrm{n} & =\text { jumlah sampel } \\
\mathrm{D} & =\text { Selisih } \mathrm{X}_{1} \text { dan } \mathrm{X}_{2} \\
\overline{\mathrm{D}} & =\text { nilai rata-rata dari } \mathrm{D}
\end{aligned}
$$

\section{HASIL PENELITIAN DAN PEMBA- HASAN}

Bentuk petak yang digunakan dalam penelitian ini terdapat tiga set yang akan dimainkan oleh tiga orang siswa secara bersama-sama. Satu orang bermain di set yang bernilai ratusan, satu orang bermain di set puluhan, dan satu orang lagi di set satuan.
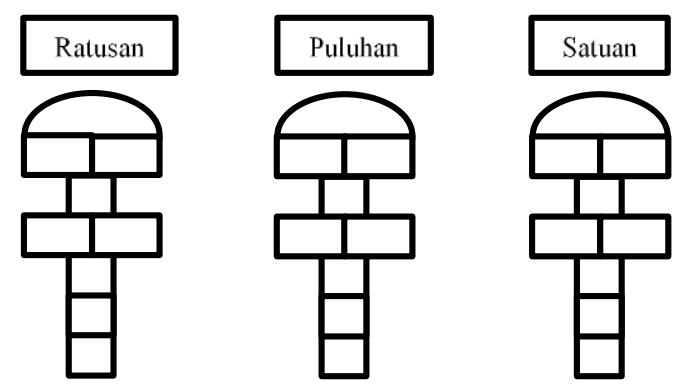

Gambar 2. Petak permainan engklek 
Adapun langkah-langkah pada penelitian ini adalah:

1. Siapkan tiga orang siswa yang akan bermain.

2. Masing-masing diminta untuk melemparkan batu ke dalam kotak, dimulai dari kotak pertama hingga terakhir.

3. Setelah batu masuk ke kotak, masingmasing anak melompati kotak menggunakan satu kaki, lalu kembali dan mengambil batu yang telah dilemparkan.

4. Setelah kembali di luar set permainan siswa diminta untuk menyebutkan batu yang mereka ambil terdapat pada kotak angka berapa.

5. Setelah itu siswa diminta untuk mengidentifikasi berapa nilai dari batu yang diambil tadi.

6. Setelah selesai, lalu siswa diminta untuk menjumlahkan semua nilai dari masing-masing pemain dan menuliskannya pada lembar yang telah disediakan.

Sebelum siswa bermain tradisional engklek, siswa diberi tes untuk mengetahui kemampuan awalnya. Setelah diberi pretest, kemudian diberi perlakuan permainan tradisional engklek. Adapun hasilnya dapat dilihat pada Tabel 1 dan Tabel 2.

Tabel 1. Deskripsi pretest

\begin{tabular}{lrr}
\hline $\mathrm{N}$ & Valid & 20 \\
\cline { 2 - 3 } & Missing & 0 \\
\hline Mean & 86,00 \\
\hline Median & 100,00 \\
\hline Mode & 100 \\
\hline Std. Deviation & 23,214 \\
\hline Minimum & 27 \\
\hline Maximum & 100 \\
\hline
\end{tabular}

Tabel 2. Deskripsi posttest

\begin{tabular}{lrr}
\hline N & Valid & 21 \\
\cline { 2 - 3 } & Missing & 0 \\
\hline Mean & 75,14 \\
\hline Median & 80,00 \\
\hline Moden & 93 \\
\hline Std. Deviatio & 22,749 \\
\hline Minimum & 27 \\
\hline Maximum & 100 \\
\hline
\end{tabular}

Hasil pretest dan posttest pada penelitian dapat dilihat pada Tabel 3 .

Tabel 3. Hasil pretest dan posttest

\begin{tabular}{crcc}
\hline No. & Data & Mean & Stdev \\
\hline 1 & Pre Test & 75,14 & 22,749 \\
\hline 2 & Post Test & 86,00 & 23,214 \\
\hline
\end{tabular}

Berdasarkan tabel di atas, mean atau nilai rata-rata dari hasil pre test adalah 75,14 dan post test sebesar 86,00. Artinya terdapat peningkatan sebesar 10,86. Dari hasil perhitungan dengan menggunakan uji $\mathrm{t}$ didapatkan nilai $\mathrm{t}_{\text {hitung }}=5,7$ dengan daerah kritis $(D K)=\{\mathrm{t} / \mathrm{t}>1,75\}$. Artinya permainan tradisional engklek efektif terhadap hasil belajar matematika materi nilai tempat.

Terjadinya peningkatan hasil belajar matematika karena diberikan perlakuan/treatment pada siswa berupa permainan tradisional engklek yang membuat siswa lebih antusias dalam mengikuti pembelajaran. Terlebih kegiatan pembelajaran dilakukan di luar kelas sehingga suasana lebih menyenangkan dibandingkan pembelajaran yang hanya dilakukan di dalam kelas. Selain itu, penggunaan bendera yang berbeda warna, hijau (satuan), kuning (puluhan), dan merah (ratusan), dapat membantu siswa 
untuk memilah dan memilih mana yang set engklek yang bernilai satuan, puluhan, atau ratusan. Sehingga pada saat bermain siswa sudah dapat menentukan berapa nilai yang dihasilkan setelah menyelesaikan permainan.

Siswa melempar sendiri batu atau gacok ke kotak yang dipilih, kemudian dilanjutkan dengan melewati setiap kotak dengan satu kaki dan kembali dengan membawa gacoknya. Setelah kegiatan itu dilakukan, siswa diminta untuk mengidentifikasi angka pada gacok yang berada dalam set kotak dan menentukan berapa nilainya.

Siswa yang bermain pada set satuan maka angka yang didapatkan bernilai satuan, gacok jatuh pada kotak ke 4 maka nilai dari bilangannya adalah 4 . Jika siswa bermain pada set puluhan maka angka yang didapatkan bernilai puluhan, gacok jatuh pada kotak ke 5 maka nilai dari bilangannya adalah 50. Sedangkan siswa yang bermain pada set ratusan maka angka yang didapatkan bernilai ratusan, gacok jatuh pada kotak ke 2 maka nilai dari bilangannya adalah 200. Jika dijumlahkan menjadi 254. Begitu seterusnya dilanjutkan oleh siswa yang lain secara bergantian.

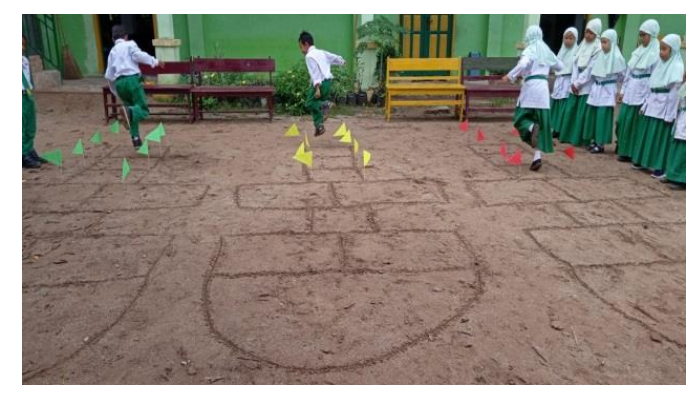

Gambar 3. Aktivitas bermain engklek

Selain siswa yang memilih sendiri kotak yang dipilih, siswa juga diminta untuk melempar gacok pada kotak yang telah ditentukan oleh guru. Misalnya pada set satuan, siswa diminta untuk melempar gacok pada kotak ketiga. Maka, siswa harus bisa melemparnya tepat di kotak ketiga. Kemudian dilanjutkan dengan melompat melewati kotak-kotak yang ada tanpa harus menginjak kotak yang terdapat gacok di dalamnya dan kembali dengan membawa gacok yang telah dilemparnya. Lalu, siswa diminta untuk menentukan nilai dari kotak tersebut. Karena sudah ditentukan pada kotak ketiga maka kotak tersebut bernilai 3 . Begitu pula seterusnya pada set puluhan dan ratusan, dilakukan oleh siswa yang lain secara bergantian. Hal inilah yang dapat membuat siswa lebih mudah menerima materi yang disampaikan sehingga hasil belajar matematika dapat meningkat.

\section{KESIMPULAN}

Permainan tradisional engklek efektif atau dapat meningkatkan hasil belajar matematika materi nilai tempat siswa Kelas 2 SD Muhammadiyah 1 Anggana. Untuk peneliti selanjutnya, dapat dijadikan bahan refrensi untuk melakukan penelitian dengan permainan atau materi jenis lain.

\section{DAFTAR PUSTAKA}

Budiyono. (2016). Statistika Untuk Penelitian, cetakan 4 edisi 2. UNS Press.

Frengky. (2008). Model pembelajaran Matematika Siswa Kelas Satu Sekolah Dasar. Jurnal Psikologi, Vol. 35, No. 2, hlm. 152. 
Hasanah, N. I. dan Pratiwi, H. (2017). Pengembangan Anak Melalui Permainan Tradisional. Aswaja Pressindo

Kandir, N. (2017). 40 Arbain Penuntut Ilmu. Pustaka Syahab.

Razak, A, dkk. (2016). Eksperimentasi Model Pembelajaran Kooperatif Tipe Group Investigation (GI) dan Think Pair Share (TPS) dengan Pendekatan Saintifik Pada Materi Relasi dan Fungsi Ditinjau Dari Kemampuan Penalaran Siswa SMP Negeri Kelas VIII di Kabupaten Karanganyar Tahun Ajaran 2014/2015. Jurnal Elektronik Pembelajaran Matema-tika, Vol. 4, No.2, hlm.216.

Razak, A dan Rumainur. (2018). Efektivitas Penggunaan Multimedia Auto play Etnik Kalimantan Timur Terhadap Hasil Belajar Matematika SD Fastabiqul Khairat Kelas VI di Kota Samarinda. JMIE: Journal of Madra-sah Ibtidaiyah Education, Vol. 2, No.1. Hlm 88.

Savitri, R. I, dkk. (2019). Peningkatan Pemahaman Konsep Nilai Tempat Bilangan Melalui Media Kantung Biji Bilangan Pada Siswa Kelas I-A Sekolah Dasar. Jurnal Pemikiran dan Pengem-bangan Sekolah Dasar, Vol. 7, No.1, hlm. 61.

Siregar, N, dan Lestari, W. (2018). Peranan Permainan Tradisional dalam Mengembangkan Kemampuan Matematika Anak Usia Sekolah Dasar. Jurnal Mercumatika: Jurnal Penelitian Matematika dan Pen-didikan Matematika, Vol. 2, No.2, hlm. 2.

Sugiyono. (2015). Metode Penelitian Pendidikan Pendekatan Kuantitatif, Kualitatif, dan $R \& D$. Alfabeta.
Suparman, E dan Agustini, D. (2017). Modul Pengembangan Keprofesian Berkelanjutan. Bandung: PPPP TK dan PLB, hlm. 23-24.

Yusri, A.Y dan Sari, M. (2017). Profile of Place Value Understanding Based on the Initial Mathematical Skills in III Class of $133^{\text {Th }}$ Primary School of Takalala Soppeng. Jurnal Mosharafa, Vol. 6, No.1, hlm. 143. 